\title{
Nutritional recommendations for individuals with Flammer syndrome
}

\author{
Zakieh Vahedian $^{1}$ - Ghasem Fakhraie ${ }^{1}$ - Jerome Bovet ${ }^{2}$ - Maneli Mozaffarieh ${ }^{2,3}$
}

Received: 23 January 2017 / Accepted: 19 April 2017 /Published online: 29 May 2017

(C) European Union 2017

\begin{abstract}
The Flammer syndrome (FS) describes the phenotype of people with a predisposition for an altered reaction of the blood vessels to stimuli like coldness or emotional stress. The question whether such people should be treated is often discussed. On the one hand, most of these subjects are healthy; on the other hand, FS seems to predispose to certain eye diseases such as normal tension glaucoma or retinitis pigmentosa or systemic diseases such as multiple sclerosis or tinnitus. A compromise between doing nothing and a drug treatment is the adaption of nutrition. But what do we mean by healthy food consumption for subjects with FS? The adaption of nutrition depends on the health condition. Whereas patients with e.g. a metabolic syndrome should reduce their calorie intake, this can be counterproductive for subjects with FS, as most subjects with FS have already a low body mass index (BMI) and the lower the BMI the stronger the FS symptoms. Accordingly, while fasting is healthy e.g. for subjects with metabolic syndrome, fasting can even dangerously aggravate the vascular dysregulation, as it has been nicely demonstrated
\end{abstract}

Maneli Mozaffarieh

maneli.mozaffarieh@gmail.com

Zakieh Vahedian

vahedian.z@gmail.com

Ghasem Fakhraie

gfakhraie@gmail.com

Jerome Bovet

jbovet@vision.tv

1 Glaucoma Service, Farabi Eye Hospital, Tehran University of Medical Sciences, Tehran, Iran

2 Augen Glattzentrum, Zurich, Switzerland

3 Department of Ophthalmology, University of Basel, Mittlere Strasse 91, 4031 Basel, Switzerland by the loss of retinal vascular regulation during fasting. To give another example, while reducing salt intake is recommended for subjects with systemic hypertensions, such a salt restriction can aggravate systemic hypotension and thereby indirectly also the vascular regulation in subjects with FS. This clearly demonstrates that such a preventive adaption of nutrition needs to be personalized.

Keywords Preventive $\cdot$ Personalized $\cdot$ Flammer syndrome Oxidative stress $\cdot$ Antioxidative nutrition

\section{Background}

The eyes, like all other organs of the body, depend upon nutrients, vitamins and minerals, to maintain their health and proper function. Thus, the way an individual eats affects the health of their eyes. Many individuals, including those with the Flammer syndrome (FS) $[1,2]$ are aware that their nutritional habits and lifestyle affect the health of their eyes, [3, 4] but may not know what they should be eating to support their eye health. The term 'Flammer Syndrome' refers to a clinical entity comprising a complex of clinical features caused mainly by dysregulation of the blood supply which has previously been called vascular dysregulation [2, 5, 6]. With an increase in allergies [7], heightened concerns over health [8], increased scrutiny of chemical additives and growing environmental concerns $[9,10]$, there is more attention being paid to nutrition and lifestyle today than perhaps ever before. Ophthalmologists are therefore often confronted with questions from people with the FS regarding nutrition. This may be partly due to the fact that people with the FS are often dissatisfied with conventional forms of treatment because they do not tolerate drugs in normal dosages as well as other people due to a different expression of ATP-binding cassette (ABC) transport proteins [11], or because the drug has produced adverse 
effects, or simply because they want to actively do something themselves for their eye health by changing their nutrition and lifestyle. In Europe, we are slowly going to where the Eastern culture has been for hundreds of years back to the idea that food is medicine and that we cannot disassociate our health with what we eat. As ophthalmologists, we are doing no harm to the patient by providing them with additional information on nutrition and lifestyle for the following reasons: it is cheap, well accepted by the patient as it has a natural source and supports the FS patient with their subjective symptoms with some first studies showing objective improvements in measures such as increased retinal venous pressure $[5,6]$, decreased systemic oxidative stress or improvements in peripheral blood flow [12-14]. It is important to note, however, that nutritional recommendations for people with FS are quite different than those with a metabolic syndrome. Accordingly, while fasting is healthy e.g. for subjects with metabolic syndrome, fasting can even dangerously aggravate the vascular dysregulation. Similarly, while reducing salt intake is recommended for subjects with systemic hypertensions, such a salt restriction can aggravate systemic hypotension [2] and thereby indirectly also the vascular regulation in subjects with FS [15]. This demonstrates that such preventive adaptation of nutrition needs to be personalized [16].

This article provides an overview of beverages and foods with potential antioxidative effect, as well as lifestyle measures an individual can take to support the FS.

\section{Main text}

\section{General background chemistry}

Nutrients with antioxidative potential [17] either contain molecules that can donate a proton to a free radical to neutralize them such as polyphenols or contain molecules with the capacity to withdraw a lone electron from free radicals such as anthocyanosides [18]. Chemically, polyphenols are defined as
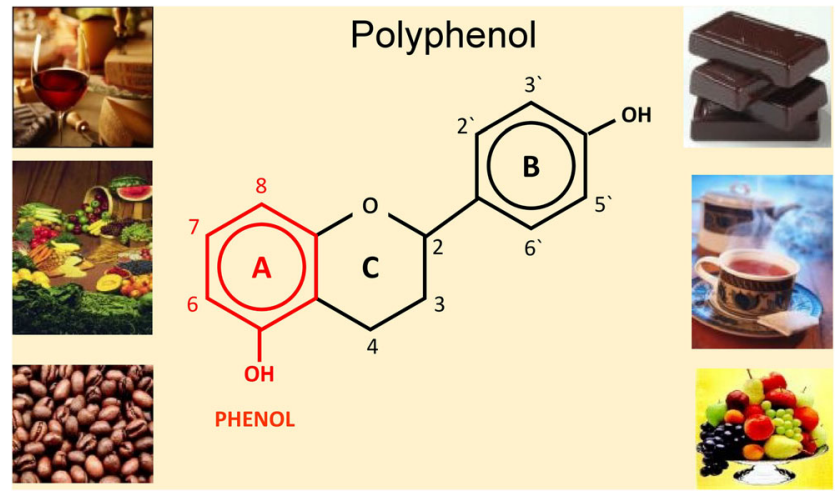

Fig. 1 The general chemical structure of a polyphenol with a phenol ring depicted in red. Alongside are foods rich in polyphenols. From: Mozaffarieh M and Flammer J. Ocular blood flow and glaucomatous optic neuropathy. 2007 Springer. Page 45 molecules having more than one hydroxyl group in their structure which can readily donate a proton to a free radical (Fig. 1), whereas anthocyanosides have a positively charged oxygen atom in their central ring with the capacity to withdraw lone electrons [19] (Fig. 2). Foods and beverages containing polyphenols or anthocyanins are generally coloured (fruits and vegetables) as the presence of conjugated double bonds creates a delocalized electron system that absorbs light between 400 and $700 \mathrm{~nm}$ of the visible wavelength.

\section{Beverages}

\section{Tea}

The source of black and green tea is the leaves of the plant Camellia sinensis [20] Fig. 3. Green tea has a much higher content of polyphenols (35\% of its dry weight) [21] including catechin (C), epicatechin (EC), epigallocatechin (EGC) and their gallate esters. The difference between the polyphenolic contents of black and green tea is the result of the different processing methods once the tea leaves are picked [22]. Once picked, black tea leaves are exposed to warm dry air where they undergo an oxidation process. This process causes the leaves to darken and brings out a full-bodied tea flavour as the catechins in black tea are converted to complex fermentation products, namely theaflavins (TFs) and thearubigins (TGs) [23]. Green tea leaves are steamed immediately after they are picked so that no oxidation occurs which is why the polyphenolic content of green tea is higher and it has a characteristic greenish-gold colour.

Tea flavonoids are scavengers of the superoxide anion and nitric oxide [24] which plays an important role in the pathogenesis of glaucomatous damage as well as of hydrogen peroxide which plays a role in UV-induced oxidative damage. Tea flavonoids inhibit the formation of lipid peroxyl radical

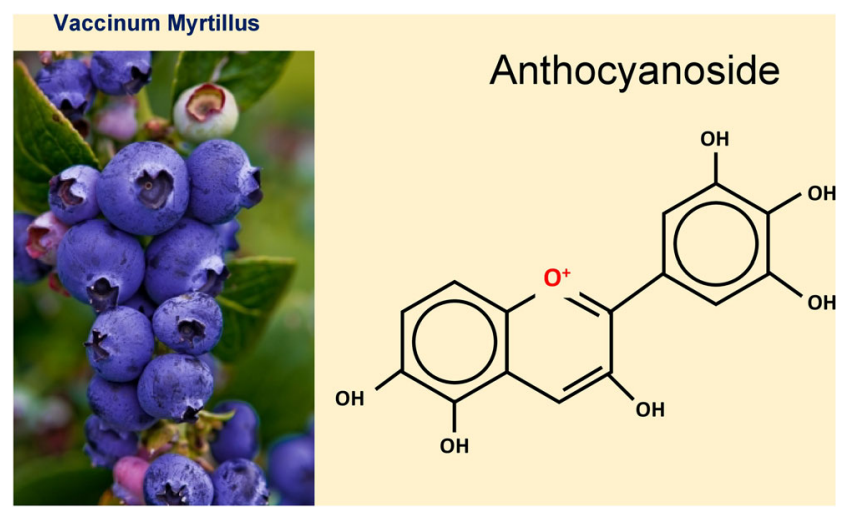

Fig. 2 Right: The general chemical structure of an anthocyanoside with a positively charged oxygen atom in the central ring which has the capacity to scavenge a free radical. Left: Blueberries rich in anthocyanosides. From: Mozaffarieh M and Flammer J. Ocular blood flow and glaucomatous optic neuropathy. 2007 Springer Page 46 


\section{Camellia Sinesis}
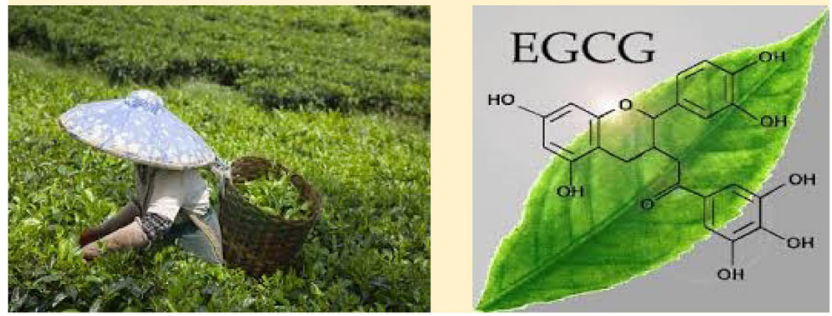

Fig. 3 Left: Green tea plantation with leaves ripe for picking. Right: Green tea leaves are rich in polyphenols such as epigallocatechin gallate. From: Mozaffarieh M and Flammer J. Ocular blood flow and glaucomatous optic neuropathy. 2007 Springer. Page 77

species and thus inhibit LDL peroxidation [25]. Tea polyphenols may have protective effects against cancer [26], although studies are controversial.

\section{Coffee}

Coffee beans have an antioxidative effect due to their polyphenols with radical scavenging and metal chelating activities [27-29] (Fig. 4). Coffee contains the molecule 3-methyl-1,2cyclopentanedione (MCP) which is a selective scavenger of peroxynitrite (ONOO-) [30]. The chemistry of MCP enables it to easily donate a proton to peroxynitrite in order to neutralize it; this is brought about by the chemical conversion of one of its carbonyl groups which becomes reduced to a hydroxyl group. Polyphenols in coffee inhibit lipid peroxidation and exert a protective effect against mutagenicity [31].

\section{Wine}

The polyphenolic content in red wine is higher than white wine [32], explaining why red wine exerts a stronger antioxidant capacity than white wines [33]. Polyphenols in wine lower the susceptibility of LDL lipids to oxidation [34] and improve endothelial dysfunction $[35,36]$ impairment which leads to damage to vascular cells and the surrounding tissue. Wine polyphenols affect endothelial function by stimulating

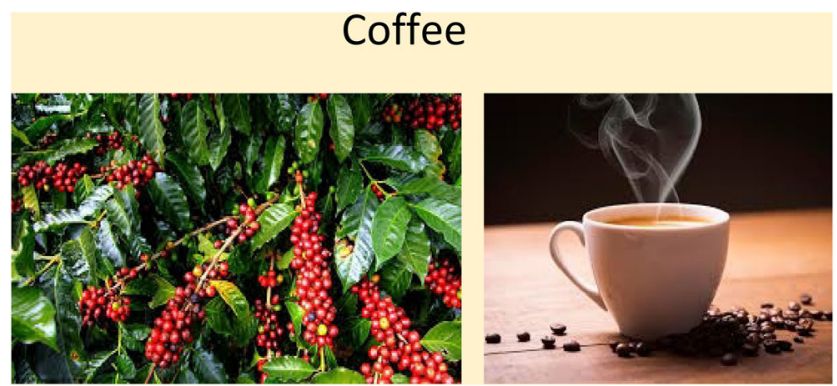

Fig. 4 On the right, a hot cup of coffee brewed from red cherry-like coffee beans from the coffee plant depicted on the left. From: Mozaffarieh M and Flammer J. Ocular blood flow and glaucomatous optic neuropathy. 2007 Springer. Page 78 the production of endothelial nitric oxide synthase (eNOS) and thus increasing the production of nitric oxide $(\mathrm{NO})$ which induces vasodilation [37]. In addition, wine polyphenols inhibit the synthesis of the potent vasoconstrictor endothelin-1 [35]. In experimental models, flavonoids in wine prevented the initiation of atherosclerotic plaque development [38, 39]. Extracellular levels of vascular endothelial growth factor (VEGF) were reduced by resveratrol [40], a polyphenol found in grapes and wine.

\section{Ginkgo biloba}

The Ginkgo biloba tree is one of the oldest trees found in fossils dating back 270 million years ago [41]. This tree is indigenous to China, Japan and Korea where it currently exists in areas of higher altitude [42], which are well drained, and adapts relatively well to different ecological conditions. The leaves and the fruits rich in flavone glycosides and terpenoids of ginkgo $[43,44]$ have been used for medical purposes for thousands of years by the Chinese.

The flavonoid glycosides confer antioxidant properties to ginkgo particularly at the mitochondrial level while the terpenoids act as antagonists of platelet-activating factor [45-48]. In comparison to other antioxidants such as vitamin $\mathrm{C}$ or vitamin $\mathrm{E}$, the extracts of ginkgo can stabilize and protect mitochondrial function [49-51] thereby preventing oxidative damage to mitochondria [49]. This property of ginkgo allows protection against retinal ischemia-reperfusion injury [52-54]. Gingko extracts inhibit LDL oxidation [55, 56], have a relaxing effect on vascular walls [57], increase ocular blood flow velocity in patients $[58,59]$, reduce systemic oxidative stress in glaucoma patients [12] (Fig. 5), and slow visual field progression in normal-tension glaucoma patients [60, 61]. A daily dosage of $120 \mathrm{mg}$ is efficient and safe [62].

\section{Borage}

Borage (Borago officinalis), also known as star flower, belongs to the flowering plant family Boraginaceae. This plant is native to the Mediterranean region but has a high resistance to cold climates and grows well in wet soils with good drainage and exposure to sunlight [63]. The beautiful violet-topurple-coloured leaves of this plant are edible, and culinary borage oil can be extracted from the seeds of this plant. Traditionally, borage was cultivated for culinary as well as medicinal uses [64-67]. The leaves of borage contain polyphenols with antioxidative effect [68] whereas the seeds are a rich source of gamma-linolenic acid (GLA) [69], with antiinflammatory effects. Borage leaves are used as an anticonvulsant [67], bronchodilator and vasodilator [70]. In a recent study, borage tea was shown to decrease increased retinal venous pressure in people with FS. This effect is most likely due to the calcium-antagonizing side effects of this plant [70]. 


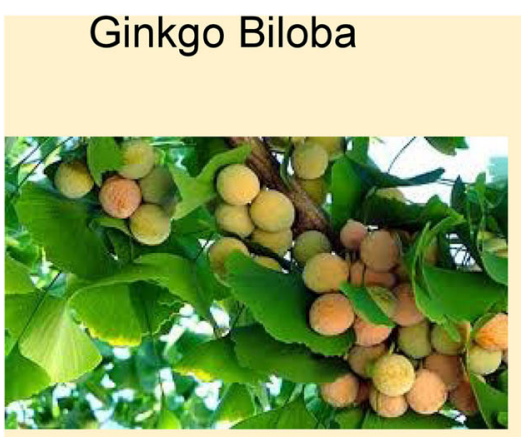

Fig. 5 Left: Ginkgo tree with fruits rich in polyphenols. Right: Ginkgo biloba significantly reduces systemic oxidative stress in glaucoma patients. From Fang L, Neutzner A, Turtschi S, Flammer J, Mozaffarieh

\section{Foods}

\section{Fruits and vegetables}

Diets rich in fruits and vegetables may reduce oxidative stress and inflammation $[71,72]$. These beneficial effects are due to their high polyphenol content which may vary from season to season [73], and on their natural stage of fruit ripening [74]. Fruits and berries blue in colour are a rich source of anthocyanosides with free radical scavenging properties [75]. These fruits exert their beneficial properties even if taken in the dried form $[76,77]$.

\section{Omega 3 fatty acids}

Omega-3 fatty acids also known as polyunsaturated fatty acids are considered essential fatty acids. Omega- 3 fatty acids are found in fish, such as salmon, tuna and halibut, other seafoods including algae and krill and flaxseed oil [78]. Omega-3 fatty acid prevents development of intracranial atherosclerosis [79], reduce inflammation [80, 81], lower blood pressure [82], improve endothelial vascular function [83] and modulate intracellular calcium ion release and thereby the stabilization of circulation [84].

Other effects include increase in the production of uncoupling proteins and improvement of ATP-independent heat production which is most probably impaired in people with FS [78, 85].

\section{Cacao}

The cacao tree or 'Theobroma cacao' is native to the deep tropical regions of Central and South America [86]. The cacao beans are a rich source of polyphenolic flavonoids whose antioxidant capacity has been shown to be higher than that of wine or green tea [87]. The amount of cacao is double as high in dark chocolate in comparison to milk chocolate [88]. Besides, the milk in milk-chocolate interferes with the

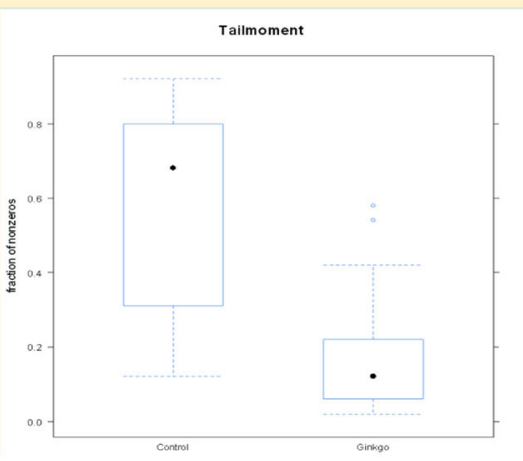

M. The effect of Gingko biloba and nifedipine on DNA breaks in circulating leukocytes of glaucoma patients. Expert Rev. Ophthalmol. 10(3), 313-318 (2015)

absorption of cacao polyphenols [89]. Consumption of cocoa-rich food, such as dark chocolate, is associated with a reduced risk for vascular disease [90-94]. This is due to the action of flavan-3-ols which augment endothelial NOS and thereby enhance the production of nitric oxide (NO), thereby improving endothelium-dependant vasorelaxation [95]. Cacao decreases blood pressure [96, 97], increases insulin sensitivity [96], increases HDL cholesterol concentrations [98] and reduces blood platelet stickiness and clotting [91, 92].

\section{Magnesium}

Magnesium can be found in a variety of foods such as seeds (chia, flax and pumpkin), avocados, tofu, nuts, legumes including beans and peas, whole grains and leafy greens. Magnesium is a physiological calcium channel blocker that partially inhibits the effect of endothelin-1 [14] and improves blood flow [13]. A dosage of 10-20 mmol daily is recommended for adults to improve the regulation of blood flow $[13,99]$. For the patient, it is important to note that the different forms of magnesium contain different amounts of

\section{Smoking and Systemic Oxidative Stress}
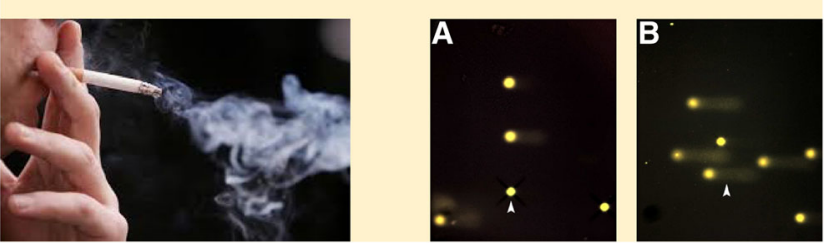

Fig. 6 An addicted smoker (left) more than doubles systemic oxidative stress as shown in the bar chart on the left where the leukocytes from the blood sample taken from the smoker show a significantly higher amount of cells with DNA breaks depicted as comet tails (b) in comparison to the blood sample from an age- and sex-matched healthy control with intact cells (a). From: Mozaffarieh M, Konieczka K, Hauenstein D, Schoetzau A, Flamme J. Half a pack of cigarettes a day more than doubles DNA breaks in circulating leukocytes. Tob Induc Dis. 17;8:14 (2010) 
magnesium, and in case they are uncertain of the correct daily dosage of the particular magnesium supplement, they should refer to their pharmacist. Forms of magnesium that dissolve well in liquid are more completely absorbed in the gut than less soluble forms [100].

Since this amount cannot be consumed solely by nutrition, we recommend the intake of magnesium in supplements. Unfortunately, it is difficult to compare the bioavailability of various forms of magnesium because different experimental methods and forms or qualities of magnesium supplements are used in various studies. One experimental study comparing the bioavailability of four inorganic and six organic mineral salts of magnesium suggested that although all ten organic and inorganic $\mathrm{Mg}$ salts were equally efficient in restoring blood $\mathrm{Mg}$ levels in plasma and red blood cells in rats, magnesium gluconate exhibited the highest magnesium retention and absorption values in the ten studied groups [101].

Finally, it is of note that although side effects are minimal, one potential side effect of magnesium supplementation is diarrhoea due to the osmotic activity of unabsorbed salts in the intestine and colon and the stimulation of gastric motility [102]. In case of diarrhoea, we recommend to take the supplement in small amounts throughout the day, perhaps together with some banana or bread.

\section{Spices}

There is increasing interest in the antioxidant compounds of herbs and spices not only because they retard the oxidative degradation of lipids $[103,104]$ but also because they improve the flavour of food. Spices including curcumin, safran, ginger, cinnamon and pepper contain polyphenolic flavonoids with antioxidative activity. During cooking, heat brings forward mutagenic epoxides, hydroperoxides and unsaturated aldehydes, which are carcinogenic [105]. Heating changes the nature of the membranes because of decomposition of the cell walls allowing antioxidant molecules more access to the free radical, thus enhancing antioxidant activity of certain spices during the heating process [106].

\section{Lifestyle}

There are certain lifestyle risk factors that can be changed to improve the FS. People with FS should try and avoid stress, as stress enhances levels of endothelin-1 in blood plasma leading to a vasoconstriction of the vessels [107] and induces transient myocardial ischaemia in approximately one third of patients with coronary artery disease [108]. Other bad habits to give up include smoking. Smoking reduces retinal blood flow, and the capacity of the retinal vessels to autoregulate to hyperoxia [109] more than doubles the levels of systemic oxidative stress in the body [3] (Fig. 6) and increases heart rate without affecting retinal venous pressure [4]. People with FS should take care to drink enough during the day as they tend to have a lack of thirst due to high levels of plasma endothelin-1 which upregulates the hormone prostaglandin E-2, thereby suppressing the centre of thirst in the brain [110]. Since low blood pressure is common amongst people with FS [2], an increased amount of salt intake is recommended $[15,111,112]$.

\section{Conclusion}

There is great interest today on natural compounds with antioxidative potential $[15,78]$.

Unfortunately, we still do not conclusively know whether nutritional sources of antioxidants can benefit people with FS. Growing evidence suggests, however, that oxidative stress resulting from FS may increase the risk of diseases such as glaucoma $[99,113,114]$. It is therefore worthwhile to summarize the present knowledge as nutritional and lifestyle changes with potential to reduce oxidative stress may benefit people with FS.

$A B C$, ATP-binding cassette; $C$, catechin; $E C$, epicatechin; $E G C$, epigallocatechin; $e N O S$, endothelial nitric oxide synthase; FS, Flammer syndrome; GLA, gamma-linolenic acid; $H D L$, high-density lipoprotein; $I O P$, intraocular pressure; $L D L$, low-density lipoprotein; $M C P, 3$-methyl-1,2cyclopentanedione; $N O$, nitric oxide; $T F s$, theaflavins; $T G s$, thearubigins; $U V$, ultraviolet.

\section{Compliance with ethical standards}

Funding No funding was received for this article.

Conflict of interest The authors declare that they have no conflict of interest.

\section{References}

1. Konieczka K, Ritch R, Traverso CE, Kim DM, Kook MS, Gallino A, Golubnitschaja O, Erb C, Reitsamer HA, Kida T, Kurysheva N, Yao K. Flammer syndrome. EPMA J. 2014;5(1):11. doi:10.1186/ 1878-5085-5-11.

2. Mozaffarieh M, Fontana Gasio P, Schötzau A, Orgül S, Flammer J, Kräuchi K. Thermal discomfort with cold extremities in relation to age, gender, and body mass index in a random sample of a Swiss urban population. Popul Health Metr. 2010;8:17. doi:10. 1186/1478-7954-8-17.

3. Mozaffarieh M, Konieczka K, Hauenstein D, Schoetzau A, Flammer J. Half a pack of cigarettes a day more than doubles DNA breaks in circulating leukocytes. Tob Induc Dis. 2010;8: 14. doi:10.1186/1617-9625-8-14.

4. Vahedian Z, Amini H, Tehrani MH, Zarei R, Moghimi S, Mozaffarieh M, Fakhraie G. Retinal venous pressure in chronic smokers. EPMA J. 2015;6(1):8. doi:10.1186/s13167-015-0031-5. 
5. Fang L, Baertschi M, Mozaffarieh M. The effect of flammersyndrome on retinal venous pressure. BMC Ophthalmol. 2014;14:121. doi:10.1186/1471-2415-14-121.

6. Fang L, Turtschi S, Mozaffarieh M. The effect of nifedipine on retinal venous pressure of glaucoma patients with the Flammersyndrome. Graefes Arch Clin Exp Ophthalmol. 2015;253(6):9359.

7. Crans Yoon AM, Chiu V, Rana JS, Sheikh J. Association of allergic rhinitis, coronary heart disease, cerebrovascular disease, and all-cause mortality. Ann Allergy Asthma Immunol. 2016;117(4):359-64.

8. Polidori D, Sanghvi A, Seeley RJ, Hall KD. How strongly does appetite counter weight loss? Quantification of the feedback control of human energy intake. Obesity (Silver Spring). 2016;24(11):2289-95.

9. Zhao R, Chen S, Wang W, Huang J, Wang K, Liu L, Wei S. The impact of short-term exposure to air pollutants on the onset of outof-hospital cardiac arrest: a systematic review and meta-analysis. Int J Cardiol. 2017;226:110-7.

10. von Holst C, Robouch P, Bellorini S, González de la Huebra MJ, Ezerskis Z. The work of the European Union Reference Laboratory for Food Additives (EURL) and its support for the authorisation process of feed additives in the European Union: a review. Food Addit Contam Part A Chem Anal Control Expo Risk Assess. 2016;33(1):66-77.

11. Wunderlich K, Zimmerman C, Gutmann H, Teuchner B, Flammer $\mathrm{J}$, Drewe J. Vasospastic persons exhibit differential expression of ABC-transport proteins. Mol Vis. 2003;9:756-61.

12. Fang L, Neutzner A, Turtschi S, Flammer J, Mozaffarieh M. The effect of Ginkgo biloba and nifedipine on DNA breaks in circulating leukocytes of glaucoma patients. Expert Rev Ophthalmol. 2015;10(3):313-8.

13. Gaspar A, Gasser P, Flammer J. The influence of magnesium on visual field and peripheral vasospasm in glaucoma. Ophthalmologica. 1995;209(1):11-3.

14. Dettmann ES, Lüscher TF, Flammer J, Haefliger IO. Modulation of endothelin-1-induced contractions by magnesium/calcium in porcine ciliary arteries. Graefes Arch Clin Exp Ophthalmol. 1998;236(1):47-51.

15. Mozaffarieh M, Fraenkl S, Konieczka K, Flammer J. Targeted preventive measures and advanced approaches in personalised treatment of glaucoma neuropathy. EPMA J. 2010;1(2):229-35.

16. Golubnitschaja O, Baban B, Boniolo G, Wang W, Bubnov R, Kapalla M, Krapfenbauer K, Mozaffari M, Costigliola V. Medicine in the early twenty-first century: paradigm and anticipation—EPMA position paper 2016. EPMA J. 2016;7:23.

17. Mozaffarieh M, Grieshaber MC, Orgül S, Flammer J. The potential value of natural antioxidative treatment in glaucoma. Surv Ophthalmol. 2008;53(5):479-505.

18. Mozaffarieh M, Flammer J. Ocular blood flow and glaucomatous optic neuropathy. Springer; 2009.

19. Flammer J, Mozaffarieh M, Bebie H. Redox reactions. In: Basic sciences in ophthalmology: physics and chemistry. Springer Science \& Business Media; 2013. pp 160-167.

20. Gramza-Michałowska A, Kobus-Cisowska J, Kmiecik D, Korczak J, Helak B, Dziedzic K, Górecka D. Antioxidative potential, nutritional value and sensory profiles of confectionery fortified with green and yellow tea leaves (Camellia sinensis). Food Chem. 2016;211:448-54.

21. Mattila P, Hellström J, Törrönen R. Phenolic acids in berries, fruits, and beverages. J Agric Food Chem. 2006;54(19):7193-9.

22. Neilson AP, Green RJ, Wood KV, Ferruzzi MG. High-throughput analysis of catechins and theaflavins by high performance liquid chromatography with diode array detection. J Chromatogr A. 2006;1132(1-2):132-40.
23. Peluso I, Serafini M. Antioxidants from black and green tea: from dietary modulation of oxidative stress to pharmacological mechanisms. Br J Pharmacol. 2016; doi:10.1111/bph.13649.

24. Nakagawa T, Yokozawa $T$. Direct scavenging of nitric oxide and superoxide by green tea. Food Chem Toxicol. 2002;40(12):1745-50.

25. Zhao B, Guo Q, Xin W. Free radical scavenging by green tea polyphenols. Methods Enzymol. 2001;335:217-31.

26. Niedzwiecki A, Roomi MW, Kalinovsky T, Rath M. Anticancer efficacy of polyphenols and their combinations. Nutrients. 2016;8(9). doi: 10.3390/nu8090552.

27. Patay ÉB, Sali N, Köszegi T, Csepregi R, Balázs VL, Németh TS, Németh T, Papp N. Antioxidant potential, tannin and polyphenol contents of seed and pericarp of three Coffea species. Asian Pac J Trop Med. 2016;9(4):366-71.

28. Wen X, Takenaka M, Murata M, Homma S. Antioxidative activity of a zinc-chelating substance in coffee. Biosci Biotechnol Biochem. 2004;68(11):2313-8.

29. Wen X, Enokizo A, Hattori H, Kobayashi S, Murata M, Homma $\mathrm{S}$. Effect of roasting on properties of the zinc-chelating substance in coffee brews. J Agric Food Chem. 2005;53(7):2684-9.

30. Kim AR, Zou Y, Kim HS, Choi JS, Chang GY, Kim YJ, Chung HY. Selective peroxynitrite scavenging activity of 3-methyl-1, 2cyclopentanedione from coffee extract. J Pharm Pharmacol. 2002;54(10):1385-92.

31. Stadler RH, Turesky RJ, Müller O, Markovic J, LeongMorgenthaler PM. The inhibitory effects of coffee on radicalmediated oxidation and mutagenicity. Mutat Res. 1994;308(2): 177-90.

32. Hernández-Jiménez A, Gil-Muñoz R, Ruiz-García Y, López-Roca JM, Martinez-Cutillas A, Gómez-Plaza E. Evaluating the polyphenol profile in three segregating grape (Vitis vinifera L.) populations. J Anal Methods Chem. 2013;2013:572896. doi:10.1155/ 2013/572896.

33. Seeram NP, Aviram M, Zhang Y, Henning SM, Feng L, Dreher M, Heber D. Comparison of antioxidant potency of commonly consumed polyphenol-rich beverages in the United States. J Agric Food Chem. 2008;56(4):1415-22.

34. van Golde PH, Sloots LM, Vermeulen WP, Wielders JP, Hart HC, Bouma BN, van de Wiel A. The role of alcohol in the anti low density lipoprotein oxidation activity of red wine. Atherosclerosis. 1999;147(2):365-70.

35. López-Sepúlveda R, Gómez-Guzmán M, Zarzuelo MJ, Romero M, Sánchez M, Quintela AM, Galindo P, O’Valle F, Tamargo J, Pérez-Vizcaíno F, Duarte J, Jiménez R. Red wine polyphenols prevent endothelial dysfunction induced by endothelin-1 in rat aorta: role of NADPH oxidase. Clin Sci (Lond). 2011;120(8): 321-33.

36. López-Sepúlveda R, Jiménez R, Romero M, Zarzuelo MJ, Sánchez M, Gómez-Guzmán M, Vargas F, O’Valle F, Zarzuelo A, Pérez-Vizcaíno F, Duarte J. Wine polyphenols improve endothelial function in large vessels of female spontaneously hypertensive rats. Hypertension. 2008;51(4):1088-95.

37. Duluc L, Jacques C, Soleti R, Iacobazzi F, Simard G, Andriantsitohaina R. Modulation of mitochondrial capacity and angiogenesis by red wine polyphenols via estrogen receptor, NADPH oxidase and nitric oxide synthase pathways. Int $\mathrm{J}$ Biochem Cell Biol. 2013;45(4):783-91.

38. Scoditti E, Calabriso N, Massaro M, Pellegrino M, Storelli C, Martines G, De Caterina R, Carluccio MA. Mediterranean diet polyphenols reduce inflammatory angiogenesis through MMP-9 and COX-2 inhibition in human vascular endothelial cells: a potentially protective mechanism in atherosclerotic vascular disease and cancer. Arch Biochem Biophys. 2012;527(2):81-9.

39. Hayek T, Fuhrman B, Vaya J, Rosenblat M, Belinky P, Coleman $\mathrm{R}$, Elis A, Aviram M. Reduced progression of atherosclerosis in 
apolipoprotein E-deficient mice following consumption of red wine, or its polyphenols quercetin or catechin, is associated with reduced susceptibility of LDL to oxidation and aggregation. Arterioscler Thromb Vasc Biol. 1997;17(11):2744-52.

40. Lançon A, Frazzi R, Latruffe N. Anti-oxidant, anti-inflammatory and anti-angiogenic properties of resveratrol in ocular diseases. Molecules. 2016;21(3):304. doi:10.3390/molecules21030304.

41. Sun B, Dilcher DL, Beerling DJ, Zhang C, Yan D, Kowalski E. Variation in Ginkgo biloba L. leaf characters across a climatic gradient in China. Proc Natl Acad Sci U S A. 2003;100(12): 7141-6.

42. Kaur P, Chaudhary A, Singh RD, Gopichand, Prasad R, Singh B. Spatial and temporal variation of secondary metabolite profiles in Ginkgo biloba leaves. Chem Biodivers. 2012;9(2):409-17.

43. Wang CZ, Yuan JJ, Li WJ, Zhang HY, Ye JZ. In vivo and in vitro toxicity evaluation of polyprenols extracted from Ginkgo biloba L. leaves. Molecules. 2015;20(12):22257-71.

44. Xie H, Wang JR, Yau LF, Liu Y, Liu L, Han QB, Zhao Z, Jiang ZH. Quantitative analysis of the flavonoid glycosides and terpene trilactones in the extract of Ginkgo biloba and evaluation of their inhibitory activity towards fibril formation of $\beta$-amyloid peptide. Molecules. 2014;19(4):4466-78.

45. Koczka N, Móczár Z, Stefanovits-Bányai É, Ombódi A. Differences in antioxidant properties of ginkgo leaves collected from male and female trees. Acta Pharma. 2015;65(1):99-104.

46. Tulsulkar J, Shah ZA. Ginkgo biloba prevents transient global ischemia-induced delayed hippocampal neuronal death through antioxidant and anti-inflammatory mechanism. Neurochem Int. 2013;62(2):189-97.

47. Koch E. Inhibition of platelet activating factor (PAF)-induced aggregation of human thrombocytes by ginkgolides: considerations on possible bleeding complications after oral intake of Ginkgo biloba extracts. Phytomedicine. 2005;12(1-2):10-6.

48. Wu Y, Sun J, George J, Ye H, Cui Z, Li Z, Liu Q, Zhang Y, Ge D, Liu Y. Study of neuroprotective function of Ginkgo biloba extract (EGb761) derived-flavonoid monomers using a three-dimensional stem cell-derived neural model. Biotechnol Prog. 2016;32(3): 735-44.

49. Eckert A, Keil U, Kressmann S, Schindowski K, Leutner S, Leutz S, Müller WE. Effects of EGb 761® Ginkgo biloba extract on mitochondrial function and oxidative stress. Pharmacopsychiatry. 2003;36(S1):S15-23.

50. Eckert A. Mitochondrial effects of Ginkgo biloba extract. Int Psychogeriatr. 2012;24(Suppl 1):S18-20.

51. Abdel-Kader R, Hauptmann S, Keil U, Scherping I, Leuner K, Eckert A, Müller WE. Stabilization of mitochondrial function by Ginkgo biloba extract (EGb 761). Pharmacol Res. 2007;56(6): 493-502.

52. Kim SY, Kwak JS, Shin JP, Lee SH. The protection of the retina from ischemic injury by the free radical scavenger EGb 761 and zinc in the cat retina. Ophthalmologica. 1998;212(4):268-74.

53. Droy-Lefaix MT, Menerath JM, Szabo-Tosaki E, Guillaumin D, Doly M. Protective effect of EGb 761 on ischemia-reperfusion damage in the rat retina. Transplant Proc. 1995;27(5):2861-2.

54. Clostre F. Protective effects of a Ginkgo biloba extract (EGb 761) on ischemia-reperfusion injury. Therapie. 2001;56(5):595-600.

55. Ou HC, Lee WJ, Lee IT, Chiu TH, Tsai KL, Lin CY, Sheu WH. Ginkgo biloba extract attenuates oxLDL-induced oxidative functional damages in endothelial cells. J Appl Physiol (1985). 2009;106(5):1674-85.

56. Pierre S, Lesnik P, Moreau M, Bonello L, Droy-Lefaix MT, Sennoune S, Duran MJ, Pressley TA, Sampol J, Chapman J, Maixent JM. The standardized Ginkgo biloba extract Egb-761 protects vascular endothelium exposed to oxidized low density lipoproteins. Cell Mol Biol (Noisy-le-grand). 2008;54(Suppl): OL1032-42.
57. Wu Y, Li S, Cui W, Zu X, Du J, Wang F. Ginkgo biloba extract improves coronary blood flow in healthy elderly adults: role of endothelium-dependent vasodilation. Phytomedicine. 2008;15(3): 164-9.

58. Chung HS, Harris A, Kristinsson JK, Ciulla TA, Kagemann C, Ritch R. Ginkgo biloba extract increases ocular blood flow velocity. J Ocul Pharmacol Ther. 1999;15(3):233-40.

59. Park JW, Kwon HJ, Chung WS, Kim CY, Seong GJ. Short-term effects of Ginkgo biloba extract on peripapillary retinal blood flow in normal tension glaucoma. Korean J Ophthalmol. 2011;25(5): 323-8.

60. Quaranta L, Bettelli S, Uva MG, Semeraro F, Turano R, Gandolfo E. Effect of Ginkgo biloba extract on preexisting visual field damage in normal tension glaucoma. Ophthalmology. 2003;110(2): 359-62.

61. Lee J, Sohn SW, Kee C. Effect of Ginkgo biloba extract on visual field progression in normal tension glaucoma. J Glaucoma. 2013;22(9):780-4.

62. Gauthier S, Schlaefke S. Efficacy and tolerability of Ginkgo biloba extract $\mathrm{EGb} 761{ }^{\circledR}$ in dementia: a systematic review and meta-analysis of randomized placebo-controlled trials. Clin Interv Aging. 2014;9:2065-77.

63. Asadi-Samani M, Bahmani M, Rafieian-Kopaei M. The chemical composition, botanical characteristic and biological activities of Borago officinalis: a review. Asian Pac J Trop Med. 2014;7S1: S22-8.

64. Abolhassani M. Antiviral activity of borage (Echium amoenum). Arch Med Sci. 2010;6(3):366-9.

65. Bamford JT, Ray S, Musekiwa A, van Gool C, Humphreys R, Ernst E. Oral evening primrose oil and borage oil for eczema. Cochrane Database Syst Rev. 2013;4:CD004416. doi:10.1002/ 14651858.CD004416.

66. Asadollahi F, Mehrzad J, Chaichi MJ, Taghavi Razavizadeh A. Photoimmunological properties of borage in bovine neutrophil in vitro model. J Photoche Photobiol B. 2015;151:270-5.

67. Al-Khamees WA, Schwartz MD, Alrashdi S, Algren AD, Morgan BW. Status epilepticus associated with borage oil ingestion. J Med Toxicol. 2011;7(2):154-7.

68. Segovia F, Lupo B, Peiró S, Gordon MH, Almajano MP. Extraction of antioxidants from borage (Borago officinalis L.) leaves - optimization by response surface method and application in oil-in-water emulsions. Antioxidants (Basel). 2014;3(2):339 57.

69. Morteza E, Akbari GA, Moaveni P, Alahdadi I, Bihamta MR, Hasanloo T, Joorabloo A. Compositions of the seed oil of the Borago officinalis from Iran. Nat Prod Res. 2015;29(7):663-6.

70. Gilani AH, Bashir S, Khan AU. Pharmacological basis for the use of Borago officinalis in gastrointestinal, respiratory and cardiovascular disorders. J Ethnopharmacol. 2007;114(3):393-9.

71. Gomes SM, Ghica ME, Rodrigues IA, de Souza GE, OliveiraBrett AM. Flavonoids electrochemical detection in fruit extracts and total antioxidant capacity evaluation. Talanta. 2016;154:284 91.

72. Mamun S, Shaheen N, Basak TA, Mohiduzzaman M, Banu CP, Takano-Ishikawa Y. Hydrophilic antioxidant capacities and total phenol content of seasonal fruits of Bangladesh. Malays J Nutr. 2012;18(3):355-62.

73. Bujor OC, Le Bourvellec C, Volf I, Popa VI, Dufour C. Seasonal variations of the phenolic constituents in bilberry (Vaccinium myrtillus L.) leaves, stems and fruits, and their antioxidant activity. Food Chem. 2016;213:58-68.

74. Rodríguez JC, Gómez D, Pacetti D, Núñez O, Gagliardi R, Frega NG, Ojeda ML, Loizzo MR, Tundis R, Lucci P. Effects of the fruit ripening stage on antioxidant capacity, total phenolics, and polyphenolic composition of crude palm oil from interspecific hybrid 
Elaeis oleifera $\times$ Elaeis guineensis. J Agric Food Chem. 2016;64(4):852-9.

75. Piljac-Žegarac J, Belščak A, Piljac A. Antioxidant capacity and polyphenolic content of blueberry (Vaccinium corymbosum L.) leaf infusions. J Med Food. 2009;12(3):608-14.

76. Oszmiański J, Lachowicz S. Effect of the production of dried fruits and juice from chokeberry (Aronia melanocarpa L.) on the content and antioxidative activity of bioactive compounds. Molecules. 2016;21(8). doi: 10.3390/molecules21081098.

77. Hooshmand S, Kumar A, Zhang JY, Johnson SA, Chai SC, Arjmandi BH. Evidence for anti-inflammatory and antioxidative properties of dried plum polyphenols in macrophage RAW 264.7 cells. Food Funct. 2015;6(5):1719-25.

78. Mozaffarieh M, Flammer J. A novel perspective on natural therapeutic approaches in glaucoma therapy. Expert Opin Emerg Drugs. 2007;12(2):195-8.

79. Shen J, Hafeez A, Stevenson J, Yang J, Yin C, Li F, Wang S, Du H, Ji X, Rafols JA, Geng X, Ding Y. Omega-3 fatty acid supplement prevents development of intracranial atherosclerosis. Neuroscience. 2016;334:226-35.

80. Harvey LD, Yin Y, Attarwala IY, Begum G, Deng J, Yan HQ, Dixon CE, Sun D. Administration of DHA reduces endoplasmic reticulum stress-associated inflammation and alters microglial or macrophage activation in traumatic brain injury. ASN Neuro. 2015;7(6). doi: 10.1177/1759091415618969.

81. Li CC, Yang HT, Hou YC, Chiu YS, Chiu WC. Dietary fish oil reduces systemic inflammation and ameliorates sepsis-induced liver injury by up-regulating the peroxisome proliferatoractivated receptor gamma-mediated pathway in septic mice. $\mathrm{J}$ Nutr Biochem. 2014;25(1):19-25.

82. Hoshi T, Wissuwa B, Tian Y, Tajima N, Xu R, Bauer M, Heinemann SH, Hou S. Omega-3 fatty acids lower blood pressure by directly activating large-conductance $\mathrm{Ca} 2+$-dependent $\mathrm{K}+$ channels. Proc Natl Acad Sci U S A. 2013;110(12):4816-21.

83. Casanova MA, Medeiros F, Trindade M, Cohen C, Oigman W, Neves MF. Omega-3 fatty acids supplementation improves endothelial function and arterial stiffness in hypertensive patients with hypertriglyceridemia and high cardiovascular risk. J Am Soc Hypertens. 2016; doi:10.1016/j.jash.2016.10.004.

84. Engler MB. Vascular relaxation to omega-3 fatty acids: comparison to sodium nitroprusside, nitroglycerin, papaverine, and D600. Cardiovas Drugs Ther. 1992;6(6):605-10.

85. Cha SH, Fukushima A, Sakuma K, Kagawa Y. Chronic docosahexaenoic acid intake enhances expression of the gene for uncoupling protein 3 and affects pleiotropic mRNA levels in skeletal muscle of aged C57BL/6NJcl mice. J Nutr. 2001;131(10): 2636-42.

86. Verna R. The history and science of chocolate. Malays J Pathol. 2013;35(2):111-21.

87. Lee KW, Kim YJ, Lee HJ, Lee CY. Cocoa has more phenolic phytochemicals and a higher antioxidant capacity than teas and red wine. J Agric Food Chem. 2003;51(25):7292-5.

88. da Silva Medeiros N, Koslowsky Marder R, Farias Wohlenberg M, Funchal C, Dani C. Total phenolic content and antioxidant activity of different types of chocolate, milk, semisweet, dark, and soy, in cerebral cortex, hippocampus, and cerebellum of Wistar rats. Biochem Res Int. 2015;2015:294659. doi:10.1155/ 2015/294659.

89. Roura E, Andrés-Lacueva C, Estruch R, Mata-Bilbao ML, Izquierdo-Pulido M, Waterhouse AL, Lamuela-Raventós RM. Milk does not affect the bioavailability of cocoa powder flavonoid in healthy human. Ann Nutr Metab. 2007;51(6):493-8.

90. Flammer AJ, Sudano I, Wolfrum M, Thomas R, Enseleit F, Périat D, Kaiser P, Hirt A, Hermann M, Serafini M, Lévêques A, Lüscher TF, Ruschitzka F, Noll G, Corti R. Cardiovascular effects of flavanol-rich chocolate in patients with heart failure. Eur Heart J. 2012;33(17):2172-80.

91. Flammer AJ, Hermann F, Sudano I, Spieker L, Hermann M, Cooper KA, Serafini M, Lüscher TF, Ruschitzka F, Noll G, Corti R. Dark chocolate improves coronary vasomotion and reduces platelet reactivity. Circulation. 2007;116(21):2376-82.

92. Rull G, Mohd-Zain ZN, Shiel J, Lundberg MH, Collier DJ, Johnston A, Warner TD, Corder R. Effects of high flavanol dark chocolate on cardiovascular function and platelet aggregation. Vasc Pharmacol. 2015;71:70-8.

93. Heiss C, Sansone R, Karimi H, Krabbe M, Schuler D, RodriguezMateos A, Kraemer T, Cortese-Krott MM, Kuhnle GG, Spencer JP, Schroeter H, Merx MW, Kelm M. Impact of cocoa flavanol intake on age-dependent vascular stiffness in healthy men: a randomized, controlled, double-masked trial. Age (Dordr). 2015;37(3):9794. doi:10.1007/s11357-015-9794-9.

94. Rassaf T, Rammos C, Hendgen-Cotta UB, Heiss C, Kleophas W, Dellanna F, Floege J, Hetzel GR, Kelm M. Vasculoprotective effects of dietary cocoa flavanols in patients on hemodialysis: a double-blind, randomized, placebo-controlled trial. Clini J Am Soc Nephrol. 2016;11(1):108-18.

95. Karim M, McCormick K, Kappagoda CT. Effects of cocoa extracts on endothelium-dependent relaxation. Journal Nutr. 2000;130(8S Suppl):2105S-8S.

96. Grassi D, Desideri G, Necozione S, Lippi C, Casale R, Properzi G, Blumberg JB, Ferri C. Blood pressure is reduced and insulin sensitivity increased in glucose-intolerant, hypertensive subjects after 15 days of consuming high-polyphenol dark chocolate. J Nutr. 2008;138(9):1671-6.

97. Almoosawi S, Fyfe L, Ho C, Al-Dujaili E. The effect of polyphenol-rich dark chocolate on fasting capillary whole blood glucose, total cholesterol, blood pressure and glucocorticoids in healthy overweight and obese subjects. Br J Nutr. 2010;103(06): 842-50.

98. Martínez-López S, Sarriá B, Sierra-Cinos JL, Goya L, Mateos R, Bravo L. Realistic intake of a flavanol-rich soluble cocoa product increases HDL-cholesterol without inducing anthropometric changes in healthy and moderately hypercholesterolemic subjects. Food Funct. 2014;5(2):364-74.

99. Mozaffarieh M, Flammer J. New insights in the pathogenesis and treatment of normal tension glaucoma. Curr Opin Pharmacol. 2013;13(1):43-9.

100. Ranade VV, Somberg JC. Bioavailability and pharmacokinetics of magnesium after administration of magnesium salts to humans. Am J Ther. 2001;8(5):345-57.

101. Coudray C, Rambeau M, Feillet-Coudray C, Gueux E, Tressol JC, Mazur A, Rayssiguier Y. Study of magnesium bioavailability from ten organic and inorganic $\mathrm{Mg}$ salts in Mg-depleted rats using a stable isotope approach. Magnes Res. 2005;18(4):215-23.

102. Izzo A, Gaginella T, Capasso F. The osmotic and intrinsic mechanisms of the pharmacological laxative action of oral high doses of magnesium sulphate. Importance of the release of digestive polypeptides and nitric oxide. Magnes Res. 1996;9(2):133-8.

103. Radha Krishnan K, Babuskin S, Azhagu Saravana Babu P, Sasikala M, Sabina K, Archana G, Sivarajan M, Sukumar M. Antimicrobial and antioxidant effects of spice extracts on the shelf life extension of raw chicken meat. In J Food Microbiol. 2014;171:32-40.

104. Otunola GA, Oloyede OB, Oladiji AT, Afolayan AJ. Selected spices and their combination modulate hypercholesterolemiainduced oxidative stress in experimental rats. Biol Res. 2014;47(1):5. doi:10.1186/0717-6287-47-5.

105. D'souza HP, Prabhu HR. In vitro inhibition of lipid peroxidation in fish by turmeric (Curcuma longa). Indian J Clin Biochem. 2006;21(2):138-41. 
106. Khatun M, Eguchi S, Yamaguchi T, Takamura H, Matoba T. Effect of thermal treatment on radical-scavenging activity of some spices. Food Sci Technol Res. 2006;12(3):178-85.

107. Yammine L, Kang DH, Baun MM, Meininger JC. Endothelin-1 and psychosocial risk factors for cardiovascular disease: a systematic review. Psychosom Med. 2014;76(2):109-21.

108. Strike P, Steptoe A. Systematic review of mental stress-induced myocardial ischaemia. Euro Heart J. 2003;24(8):690-703.

109. Morgado PB, Chen HC, Patel V, Herbert L, Kohner EM. The acute effect of smoking on retinal blood flow in subjects with and without diabetes. Ophthalmology. 1994;101(7):1220-6.

110. Teuchner B, Orgül S, Ulmer H, Haufschild T, Flammer J. Reduced thirst in patients with a vasospastic syndrome. Acta Ophthalmol Scand. 2004;82(6):738-40.
111. Mozaffarieh M, Flammer J. Is there more to glaucoma treatment than lowering IOP? Surv Ophthalmol. 2007;52(6):S174-9.

112. Mozaffarieh M, Konieczka K, Schoetzau A, Flammer J. Outcomes of comet assay analysis using freshly prepared and cryopreserved leukocytes. Oxid Antioxid Med Sci. 2013;2(3):155-61.

113. Flammer J, Mozaffarieh M. The mechanism of glaucomatous damage to the optic nerve. European Ophthalmic Review. 2009;3(1):33-5.

114. Mozaffarieh M, Schoetzau A, Sauter M, Grieshaber M, Orgül S, Golubnitschaja O, Flammer J. Comet assay analysis of singlestranded DNA breaks in circulating leukocytes of glaucoma patients. Mol Vis. 2008;14:1584-8. 